\title{
XVI. Yüzyılın İkinci Yarısında Üretimden Pazara Osmanlı Köylüsünün Karşılaştığı Yapısal Sorunlar Ve Bu Sorunlara Karşı Merkezi Yönetimin Aldığı Tedbirler
}

\author{
Savaş Yılmaz*
}

(ORCID ID: 0000-0002-6979-6495)

\author{
Makale Gönderim Tarihi \\ 10.05.2019
}

\author{
Makale Kabul Tarihi \\ 19.09.2019
}

\section{Özet}

Osmanlı sosyo-ekonomik yapısının ana unsurunu üretim ile arz-talep dengesi oluşturmuştu. Üretimin asıl kaynağını ise tarım ve tarıma bağlı faktörler oluşturmaktaydı. Bu sebeple kırsal kesimdeki üretim unsurları her zaman merkezî yönetimin denetimi altında olmuştu. Tarımsal üretim sürecinde köylüler bazı olumsuzluklarla karşılaşmışlardı. Bu bağlamda yaşadıkları olumsuzlukları divâna arz eden köylülerin, hakkında Merkezî yönetimce ne gibi tedbirlerin alındığııın araştırıması gerekmişti. Köylülerin gerek beşerî sebeplere bağlı sorunları gerekse tarım alanlarının tohumla buluştuğu süreçten, elde edilen hâsılatın pazarlanmasına kadar geçen zamana kadar karşılaşmış oldukları sorunları karşııında nasıl davrandıklarının araştırılması gerekmiştir. XVI. yüzyılın ikinci yarısında köylülerin tarımsal faaliyetlerinde, emek ve sermaye etrafında klasik tarım faaliyetlerini devam ettirmeleri, tarımda yaşanan sorunlara çözüm bulamayışları, bir dönümde elde edilen ürün oranını olumsuz yönde etkilediği görülmüştür. Köylülerin klasik tarım metotlarına devam etmeleri, tarımı iklimsel koşullara bağlı yapmaları ve vergiler üzerinde bazı devlet memurlarının (ehl-i örf ile ehl-i şer') köylüleri suiistimal etmeleri karşısında Merkezî yönetimin ne gibi tedbirler aldığı da açıklanmışırı. Burada devletin, köylülerin kronik sorunları karşııındaki fonksiyonunun tespiti oldukça önem arz etmektedir. Osmanlı Devleti, tarım alanlarının ekilip biçilmesi ile köylülerden tahsil edeceği vergilerin toplanmasına oldukça önem vermesine rağmen köylülerin klasik tarımsal faaliyetleri dışında topraklarını ekip biçmeleri haricinde köylüleri organize edemediği gibi onların gerek tahsildarlar tarafından gerekse konar-göçer ile eşkıyalar tarafından istismar edilmelerine de tam anlamıyla mani olamamıştı. Bu bağlamda Merkezî yönetim XVI. yüzyılın ikinci yarısında, kırsal yerlerde

\footnotetext{
*Dr., Milli Eğitim Bakanlığı, syilmaz3840@hotmail.com.
}

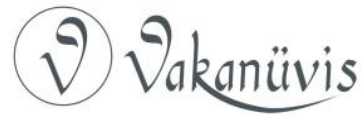


sağlanan vergi gelirlerinin azalmamasına ve şehirlerin temel gıda maddelerinin (hububat ve et vs.) sağlanmasında güçlüklerin yaşanmamasına önem vermişti.

XVI. yüzyılın ikinci yarısında tarımsal üretimin önemli bir sacayağını oluşturan köylülerin üretimden pazara karşılaştıkları sorunların neler olduğu, yetiştirmiş oldukları ürünlerin pazarlanmasında ne gibi zorluklarla karşılaştıkları ve yaşanan sorunların tarımsal faaliyetler üzerindeki tesirleri mühimme defterlerine istinaden ele alınıp incelenmiştir. Devletin en önemli gelir kalemleri arasında tarımsal faaliyetlerde elde edilen vergiler oluşturmaktaydı. Bu bağlamda Osmanlı Devleti, köylülerin karşılaştıkları sorunları Divân-ı hümâyûna arzları neticesinde ne gibi kararlar aldığı, sosyoekonomik yapı içerisinde önemli bir yere sahip olan reâyânın/köylülerin, üretimden pazara kadar geçen süreçte karşılaştıkları beşerî ve doğal sorunların, üretim üzerindeki etkileri araştırılmıştır.

Anahtar Kelimeler: XVI. yüzyıl, Osmanlı Devleti, Divân-ı Hümâyûn, Köylü, Üretim, Kıtlık, Vergi, Reform.

\title{
Structural Problems of Ottoman Peasants From the Production to the Market and Measures Taken by Central Administration Against these Problems in the $2^{\text {nd }}$ Part of the $16^{\text {th }}$ Century
}

\begin{abstract}
The main element of the Ottoman socio-economic structure consisted of production and supply-demand balance. The main source of production was agriculture and agriculture-related factors. For this reason, the elements of production in rural areas have always been under the control of central government. During the agricultural production process, the peasants faced some problems. In this context, the peasants who presented the negativity to the Imperial Council, wanted to be informed about what measures the central government took. It was necessary to investigate how the peasants behaved in the face of both human-related problems and the problems they faced during the period from the process of the agricultural fields where the seeds met to the marketing of the proceeds.It was explained that the peasants continued classical farming methods and made agriculture dependently on climatic conditions and what kind of measures the central government took against the abuse of the peasants in taxation by some civil servants. Here, the determination of the state's function against the chronic problems of the peasants was very important. The Ottoman State attached great importance to the cultivation of agricultural lands and the collection of taxes to be
\end{abstract}

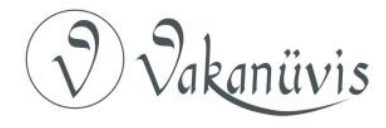


collected from the peasants. However, apart from the classical agricultural activities of the peasants, it was neither able to organize the peasants to cultivate their land, nor could fully prevent them from being exploited by the collectors and by the nomads and the bandits.In this context, the central government in the second half of the sixteenth century emphasized that the tax revenues provided in rural areas should not be reduced and that the cities would not have difficulties in providing basic foodstuffs (cereals and meat etc.).

In the second half of the sixteenth century, the problems faced by the peasants who constitute an important pillar of agricultural production, from production to market, the difficulties they faced in the marketing of the products they have grown and the effects of the problems on agricultural activities were examined with reference to the registration books. Among the most important income items of the state were taxes on agricultural activities.In this context, from production to market, the effects of human and natural problems on production faced by people / peasants who have an important place in socio-economic structure and what kind of decisions the Ottoman State took after the problems faced by the peasants were presented to the Imperial Council were investigated.

Keywords: Sixteenth Century, Ottoman Empire, Imperial Council, Peasant, Production, Scarcity, Tax, Reform.

\section{Giriş}

XVI. yüzyılın ikinci yarısında tarım alanında yaşanan sorunları tahrir defterlerinden bağımsız bir şekilde Divân-ı hümâyûnda oluşturulan mühimme defterleri ${ }^{1}$ ne göre ele alıp inceleyeceğiz. Osmanlı toplumun büyük bir kısmı köylerde yaşayarak maişiyetlerini topraktan sağlamaktaydılar. Aynı zamanda devletin, malî ve askerî yapısının oluşumunda ve tarım arazilerinin ekilip biçilmesinde köylülerin önemli bir yere sahip olduğu bilinmektedir. ${ }^{2}$ Bu bağlamda XVI. yüzyılın ikinci yarısında Osmanlı malî yapısında önemli bir yere sahip köylülerin gündelik hayatta karşılaşmıs oldukları sorunların neler olduğu ve bu sorunların çözümünde onların nasıl davrandıklarının arşiv belgeleri

\footnotetext{
${ }^{1}$ Yusuf Sarınay v.d., Başbakanlık Osmanlı Arşivi Rehberi, Başbakanlık Basımevi, Ankara, 2010, s. 7.

2 Hasan Fatih Yılmaz, 16. Yüzyıl Osmanlı Ekonomisinde Piyasa'nın Karşıtı Pazar, Ötüken Yayınları, İstanbul 2012, s. 97.
}

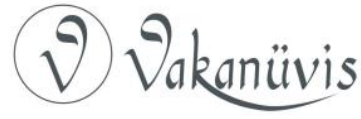


arasında yer alan mühimme defterlerine göre ele alınıp incelenmesi gerekmiştir.

Köylülerin XVI. yüzyılın ikinci yarısında karşılaştıkları sorunlara geçmeden kısaca köy oluşumu üzeride durulmasında fayda var. Merkezî yönetim köylerin kurulmasında belirli plan dâhilinde hareket etmişti. Bunun için köy hayatının canlı tutulmasına yönelik bazı tedbirler almasına rağmen köylülere, toprakların özel mülkiyet hakkını vermemişti. ${ }^{3}$ Yani Osmanlı Devleti'nde, köylü “... irsî ve daimî bir kiracı şeklinde toprağa bağlı..."4 bulunmak zorun kalmıştı. Bu sebeple toprağı atadan ve babadan itibaren ekip biçenlere köylü denmekteydi. ${ }^{5}$ Yani "Osmanlı toprak sisteminde önemli bir unsur olan reâyâ (köylü), Osmanlı toprak sisteminde bir parya veya köle mesabesinde bulunmuyordu. Topraktan ilk mahsulü çıkaran ve onu yetiştiren reâyâ olduğu için, bizzat padişah tarafından 'nimeti temin eden efendi şeklinde tanımlanmıştı." 6 Bu bağlamda toprak ile köylü özdeşleşmişti. Bu sistemde topraktan azami ölçüde faydalanılmasına ve burada elde edilecek mahsulün tebaanın ve devletin hizmetine sunulmasına oldukça önem verilmişti. ${ }^{7}$ Ancak XVI. yüzyılın sonlarında Osmanlı Devleti değişen dünya koşullarında etkilenmişti. Osmanlı Devleti bu çevreleşme sürecinde tarımsal üretimi eskiden olduğu gibi kontrol edememişti. ${ }^{8}$ Bu bağlamda tarımsal alanda elde edilecek mahsulün maksimum seviyede olması için toprağı ekip biçen köylülerin karşılaşmış oldukları sorunların çözüme kavuşturulması gerekmişti. Özellikle tarım için hayatî öneme sahip olan su sorunun halledilmesi köylünün en öncelikle halledilmesi geren sorunlarından biriydi. Su

\footnotetext{
${ }^{3}$ Savaş Yılmaz, III. Murat Döneminde Divân-ı Hümâyûn Gündeminde Osmanlı Köyü ve Köylüsü, Gazi Üniversitesi Sosyal Bilimler Enstitüsü Yayınlanmamış Doktora Tezi, Ankara, 2017, s. 28-29.

4 Ömer Lütfi Barkan, Osmanlı Devleti'nin Sosyal ve Ekonomik Tarihi, Tetkikler Makaleler, Yayına Hazırlayan: Hüseyin Özdeğer, İstanbul Üniversitesi Rektörlük Yayınları, Cilt I, İstanbul 2000, s. 557.

${ }^{5}$ Halil İnalcık, Osmanlı Imparatorluğu Klâsik Çağ (1300-1600), Çev. Ruşen Sezer, Yapı Kredi Yayınları, 14. Baskı, İstanbul 2009, s. 223.

${ }^{6}$ Savaş Yılmaz, a.g.t., 67.

7 Sadık Albayrak, Budin Kânunnâmesi ve Osmanlı Toprak Meselesi, Tercüman Yayınları, İstanbul 1973, s. 72.

${ }^{8}$ Huricihan İslamoğlu, Osmanlı İmparatorluğu'nda Devlet ve Köylü, Illetişim Yayınları II. Baskı 2010, 58.
}

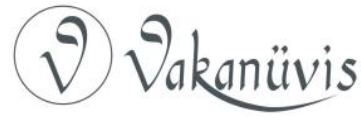


sorunun çözüme kavuşturulmadığı yerlerde klasik ekin ürünü buğday ekiminden değişikliğe gidilerek suya daha az ihtiyaç duyan kıraç arazilerde yetişebilen arpa ekimine yönelilmişti. ${ }^{9}$ Tarlaların ihtiyacı suyun sağlanamamış olmasının yanı sıra toprağın verimini artırmak için kullanılan hayvan gübrelerinin, odun fiyatlarının aşırı artmasından dolayı tezek olarak yakılması topraktan sağlanacak verimin düşmesine yol açmışı. ${ }^{10}$ Köylüler tarımsal alandaki sorunlarının çözüme kavuşturulamamasına rağmen üretim içerisinde kalarak alışılmış ekin kültüründen çıkıp coğrafyanın yapısına uygun tarımsal faaliyetler içerisinde bulunmuşlardı.

Köylüler hasat zamanında elde ettikleri ürünlerin belirli bir kısmını devlete vergi olarak verdikleri gibi geri kalan bir kısmını da pazarlarda satarak gündelik intiyaçlarını karşılamaktaydılar. ${ }^{11}$ Köylerini tabiatın bütün olumsuzluklarına rağmen terk etmeyen köylüler, aynî olarak ödedikleri vergilerin yanı sıra nakdî olarakta vergilerinin bir kısmını ödemek zorundaydılar. Bu sebeple gündelik ihtiyaçlarını karşılamak ve nakdî vergilerini ödemek için tarımsal faaliyetlerin dışında hayvancılık, bağ ile bahçecilikle de uğraşmışlardı. ${ }^{12}$ Köylüler bu süreçte üretim ile arz-talep arasında bazı sorunlar yaşamışlardı. Bu sebeple taşrada sorunlarını çözemeyen köylüler, Divân-ı hümâyûna arz-ı hallerini sunarak karşılaştıkları sorunlara çözümler aramışlardı. Köylüler, sanayi öncesi tarım toplumlarında belirgin bir biçimde ortaya çıkan tarımsal verimliliği ${ }^{13}$ artırmaya yönelik gayretlerinden ziyade beşerî ve doğal sorunlarının çözüme kavuşturulması için Divân-ı hümâyûna arzlarını sunmuşlardı.

\footnotetext{
9 Sam Whıte, Osmanlı'da İsyan İklimi Erken Modern Dönemde Celâli İsyanları, Çeviren: Nurettin Elhüseyni, Alfa Yayınları, İstanbul 2013, s. 111.

10 Sam White, a.g.e., s. 113.

${ }^{11}$ Mehmet Ali Ünal, Osmanlı Sosyal ve Ekonomik Tarihi, Paradigma Yayınları, İstanbul 2012, s. 100.

12 Huricihan İslamoğlu, a.g.e., s. 251.

${ }^{13}$ Mehmet Öz, Tarımda Verimlilik Problemi, XVI. Yüzyılda Uşak Kazası, XIII. Türk Tarih Kongresi (Kongreye Sunulan Bildiriler), Cilt III., Kısım III., Ankara 1999, s. 1648.
}

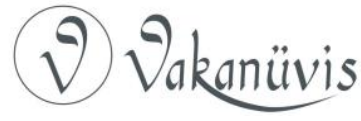




\section{Köylülerin Üretimde Karşılaştığı Sorunlar}

\section{a) İklimsel Faktörlere (Kuraklık, Sulama, Ağır Kış Şartları ile Doğal Afetler vs.) Bağlı Karşılaşılan Sorunlar}

Tarımsal verimin artırılıp maksimum seviyede toprakta istifade edilmesinde su hayatî bir öneme sahipti. Öyle ki iklimsel koşullara bağlı olarak yağmurun az yağması sebebiyle tarım alanlarında su kıtlığının yaşanması, köylülerin gündelik intiyaçlarını karşıladıkları içme sularının bir kısmını ziraatta kullanmalarını gerektirmişti. Bu bakımdan su insanların gündelik ihtiyaçlarının karşılanmasında hayatî bir öneme sahip olduğu gibi aynı zamanda da tarım alanlarında elde edilecek mahsulün oranının da belirlenmesinde önemli bir değerdi. Bu hususla ilgili olarak Necef tebaasından bazıları, Divâna arz da bulunup su sıkıntısı yaşadıklarını, kendilerine ait içme sularının bir kısmını başkaları tarafından ziraatta kullanıldığını ve suyollarının tamiri nedeniyle de kendilerinden beşte bir alınması gereken verginin sekiz de bir alınarak zulüm yapıldığını belirtmişlerdi ${ }^{14}$ Suyun hem tarımda hem de insanların gündelik hayatlarında kullanılması, susuzluğun ciddi boyutlara ulaştığını göstermektedir. İklimsel sebeplere bağlı olarak arazilerin suya ihtiyaçlarının karşılanması elzem olduğundan, içme sularından dahi arazilerin su ihtiyaçları giderilerek kuraklığa bağlı rekolte düşüşüne mani olunmak istenmişti. İklimsel sebeplere bağlı yaşanan kuraklıkla ilgili Van beylerbeyi Divâna mektup gönderip Van ve Van'a bağlı yerlerde yeterince yağmur yağmaması nedeniyle ziraat alanlarında su kıtlığının yaşandığını arz etmişti. ${ }^{15}$

Tarım arazilerinin suya ihtiyaçlarının yanı sıra yaşanan kuraklıktan dolayı içe suyunun teminde dahi zorluklar yaşanmıştı. Bu bağlamda Yanbolı kadısına gönderilen hüküm de Çeri köylülerinin Divâna susuzluktan dolayı mağdur olduklarını belirttikleri buna binaen Sofya Pınarı suyundan faydalanılarak Çeri köyüne akıtılması bu iş için ise gerekli masrafın tüccarlardan alınacak akçelerle karşılanarak Köylünün içme suyuna olan ihtiyacının ivedilikle sağlanması emredilmişti. ${ }^{16}$ Merkezî yönetim, köylülerin gerek içme gerekse tarım alanlarının su

\footnotetext{
${ }^{14}$ BOA MD, 27, h. 729, s. 305.

15 BOA MD 27, h. 734, s. 307.

${ }^{16}$ BOA MD, 48, h. 249, s. 92.
}

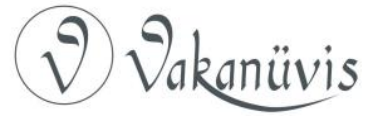


intiyaçlarının karşılanması için suya ihtiyaç duyulan yerlere yakın olan nehirlerde faydalanılması yönünde taşradaki görevlilere hükümler göndermişti. Bu şekilde alınan önlemlerle Osmanlı köylüsünün iklimsel kuraklıklara ${ }^{17}$ bağlı gerek tarım arazilerinin gerek ise içme suya olan gereksinimleri karşılanmaya çalışılmıştı.

Tarım alanlarında yaşanan iklimsel kuraklığa bağlı olarak köylüler içme sularında faydalanarak baş etmeye çalışmışlardı. Ancak su yaşamsal bir değere sahip olduğundan Merkezî yönetim içme sularının tarım havzalarında kullanılmasını men etmişti. Şöyle ki Merkezi yönetimce, Çorlu'ya getirilen suyun, kırlarda geçerken harkların her iki tarafına dörde bir ekin alanlarının olmamasına dikkat edilmesi gerektiği kadıya emredilmişti. ${ }^{18}$ Merkezi yönetim tarafından köylülerin içme suyunu tarım alanlarında kullanmamaları yönünde almış olduğu bu karar, bize köylülerin su ihtiyaçlarının karşılanmasına daha önem verildiğini göstermektedir. Aynı zamanda köylüler tarım arazilerini sulamak için köylerinde geçen içme sularında kanunsuz bir şekilde faydalanmak istemişlerdi. Çünkü susuzluğa bağı kuraklık, zahire darlığına ya da kıtlığına yol açmaktaydı. Bunun gibi bir nehirde faydalanan köylüler suyun az ya da çok kullanımından kaynaklanan sorunları Divâna arz etmişlerdi. Şam'a bağıı Burç nahiye halkından bazıları Divâna sundukları arzda nahiyelerindeki nehrin altı köyden geçtiğini ancak bu nehirde köylülerin aynı oranda faydalanmadığını belirtmişlerdi. Bunun üzerine nehrin temizliğinin yapılarak köylülerce köprünün tamir edilip nehir suyundan aynı oranda köylülerin, istifade etmeleri emredilmişti. ${ }^{19}$ Nehir suyunun kullanımından kaynaklanan sorun taşrada çözüme kavuşturulamayıp Divâna arz edilmesi, suya olan intiyacın ve iklimsel koşulların etkisiyle kuraklığın ne denli etkili olduğunu ortaya koymaktadır. Nehir sularının hem gündelik hayatta hem de tarım alanlarının kullanımında azami ölçüde faydalanılması için nehir yataklarının bakım ve onarımın yapılması Merkezi yönetimce taşradaki ehl-i şer ve ehl-i örfe emredilerek köylüler arasında yaşanması muhtemel olan sorunların önü alınmaya çalışılmıştı. Bu mecrada Mud kadısına gönderilen hükümde kazaya bağıı (?) köyde

\footnotetext{
17 Sam White, a.g.e., s. 102.

18 BOA MD 23, h. 62 , s. 31.

${ }^{19}$ BOA MD, 67, h. 116 , s. 44.
}

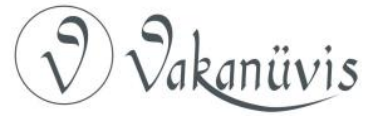


geçen nehrin, köyün mezraalarının sulanmasında hayati bir öneme sahip olduğu ve nehir suyunun Çayır Pınarı denilen yerde batarak yok olduğu bu nedenle tarım alanlarında su sıkıntısı yaşanmış olduğu belirtilmişti. Ayrıca kadıya gönderilen hükümde nehir suyunda istenilen oranda faydalanılması için nehrin tamir edilmesi işini üstlenmek isteyen Mevlana Abdüllatif'e verilmesi ve bu iş için herhangi bir zorluk çıkarılmaması gerektiği emredilmişti. ${ }^{20}$

Tarım alanlarının yeterince sulanamaması kıtlığın yaşanmasına sebep olduğu gibi aynı zamanda hayvanların beslenmesinde de önemli bir yere sahip olan saman darlığına/kıtlığına da yol açmaktaydı. Bu bağlamda Çorlu kadısı Divâna arz da bulunup samanın balyesinin bir akçeye çıktığını bu sebeple köylülerin saman temin etmekte zorluklar yaşadığını belirtmişti. ${ }^{21}$ Suyun yeterince olmayışı doğrudan tarımı etkileyerek hem mahsulün az olmasına neden olmuş hem de dolaylı yönde tarıma bağlı hayvancılığa da zarar vermişti.

Köylüler ağır kış şartlarının hâkim olduğu yerlerde de bazı olumsuzluklarla karşılaşmışlardı. Şöyle ki Of kadısı Divâna arz sunarak kış şartlarının ağır olması ve aşırı kar yağması nedeniyle yolların kapanıp bozulduğunu belirtmişti. ${ }^{22}$ Kar yağışının aşırı olması nedeniyle köylüler bağıı oldukları kazalara gidip gündelik ihtiyaçlarını karşılayamamışlardı. Bu durumu başkentin zahire ihtiyacının karşılanması için Kütahya ve havalisine gönderilen Arslan Çavuş'un ağır kış şartlarından (kar) dolayı zahireyi başkente getiremeyişinden de görebiliriz. Merkezi yönetim ise yaşanan ağır kış şartları sebebiyle başkentin zahire ihtiyacının acil karşılanması için kış şartlarıyla mücadelede develerin kiralanarak zahirenin başkente ulaştırılmasını emretmişti. ${ }^{23}$ Bunun gibi Anadolu beylerbeyine gönderilen hükümde ise Karaman ve civarında toplanan zahirenin ağır kış şartları nedeniyle Eskişehir ve Bozöyük yakınlarında kalmış olduğu bu sebeple zahirenin başkente getirilmesi için develerin kiralanmasını, bu zaman zarfında zahirenin zarar görmemesi için de ambarlara konulmasını emretmişti. ${ }^{24}$

\footnotetext{
20 BOA MD, 54, h. 64, s. 18.

${ }^{21}$ BOA MD 23, h. 451, s. 613.

22 BOA MD, 73, h. 75, s. 31.

${ }^{23}$ BOA MD 27, h. 699, s. 292.

${ }^{24}$ BOA MD 27, h. 702, s. 293.
}

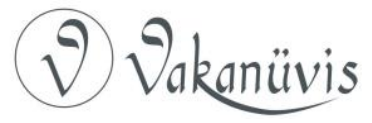


Merkezi yönetim, zahirenin başkente taşınmasında ulaşımda yaşanan ağır kış koşulları nedeniyle develerin gücünden faydalanılmasını istemişti.

İklimsel koşullara bağlı ürün darlığı/kıtlığının yaşanması bir sonraki yıl için kullanılacak tohumluğun temininde de köylülerin zorluklar yaşamasına sebep olmuştu. ${ }^{25}$ Merkezi yönetimce, devlet imkânları kullanılarak zahirenin iklim koşulları ne kadar olumsuz olursa olsun başkente taşıtma azmi ile maddi imkânları, köylülerin genelinde bulunmamaktaydı. Bu sebeple köylülerin develeri satın alacak maddi imkânlarının olmayışı, onların kış şartlarında (kar, tipi vs.) kapanan köy yollarında kazalara gidip gelmelerinde ve gündelik ihtiyaçlarını karşılamalarında sorunlar yaşamalarına yol açmıştı. Görüldüğü gibi maddi imkânsızlıklar, köylülerin en yakın kazalara gidip gelmelerinde zorluklar çıkardığı gibi sağlık sorunları yaşamalarına da sebep olmuştu. $\mathrm{Bu}$ bağlamda ağır kış şartlarından dolayı köylüler sadece ürün darlığı/kıtlığı yaşamamışlardı. Aynı zamanda ağır kış şartlarıyla mücaadele eden köylüler, arazilerini ekip biçemedikleri gibi çeşitli hastalıklara da yakalanmışlar hatta ağır kış şartlarından dolayı köylülerin donan uzuvları kesilmişti. ${ }^{26}$ Köylülerin uzuvlarının don nedeniyle kesilmesi, kangrenin bütün vücuda yayılmasının engellenmesi için yapılan bir cerrahi müdahale olmuştu.

Köylüler tarımsal faaliyetlerde bulunurken bir taraftan iklimsel koşullara (kuraklık, kar, sel vs.) bağlı tarımsal rekoltenin düşmemesi için uğraşırlarken diğer taraftan da iklimsel koşullara bağlı bazı sağlık sorunlarıyla da mücadele etmek zorunda kalmışlardı. Emeğin yoğun olarak görüldüğü tarımsal faaliyetlerde, köylüler çetin doğa şartlarıyla baş etmek zorunda kalmışlar ve bu mücadelede sağlıklarını kaybetmişlerdi. Buna rağmen üretmekten vazgeçmeyen köylüler, adeta toprak ananın onlara vereceği ürünlerle var olmayı amaçlamışlardı.

\footnotetext{
25 Mehmet Ali Ünal, a.g.e., s. 100.

${ }^{26}$ Zafer Karademir, İmparatorluğun Açlıkla İmtihanı Osmanlı Toplumunda Kıtlıklar (1560-1660), Kitap Yayınevi, II. Baskı, İstanbul 2017, s., 54.
}

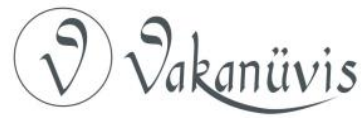




\section{b) Üretim Fazlalığı Nedeniyle Karşılaşılan Sorunlar}

İklimsel sebeplerden kaynaklanan üretim düşüklüğü nasıl köylünün gelirini düşürmüş ise hava koşullarının çok iyi gidip üretimde sağlanan rekolte fazlalığı da köylülerin geliri üzerinde doğrudan olumsuz etki yapmaktaydı. ${ }^{27}$ Hasat zamanında elde edilen ürün fazlalığı ürünlerin fiyatını düşürmekteydi. Yani arzın talepten fazla olduğu zamanlarda köylüler, yetiştirdikleri ürünlerde bekledikleri kârı sağlayamıyorlardı. Bu durum ise köylülerin, ekonomisini olumsuz etkilediği ${ }^{28}$ için köylüler, masraflarını zaman zaman karşılamakta zorlanmışlardı.

Üretimden pazara kadar geçen zaman içersinde köylülerin ciddi sorunlarla karşılaşmaları ve Merkezi yönetimin emtia fazlalığından kaynaklanan köylülerin maddi zararlarını karşılayacak plan ve projesinin olmayışı, köylerin boşalmasında başka bir etken olarak karşımıza çıkmaktadır. Her ne kadar ürün fazlalığının ya da kıtlığının yaşandığı zamanlarda devletin uyguladığı “...stok politikası..." ${ }^{29}$ hem üreticiyi hem de tüketiciyi korumuş ise de bu yöntemin işlerliği hususunda da bazı sorunlar da yaşanmıştı. Şöyle ki Şam beylerbeyine ve kadısına gönderilen hüküm de Şam'da ki ehl-i örf taifesinden bazılarının, köylülerden aldıkları zahireyi ambara stokladıkları, hububata ihtiyaç duyulduğunda, rayiç bedelinden oldukça fazlaya satarak haksız kazanç sağladıkları belirtilip bu husus hakkında gereğinin yapılması emredilmişti. ${ }^{30}$ Alınan tedbirin pazar ekonomisinin doğal koşulları arasında bulunan fiyat hareketlerini olumsuz etkileyen karaborsacılığa dönüştüğü görülmektedir.

Osmanlı Devleti'nin öncelikli amaçlarından biri halkının doyurulması idi. Bu bağlamda Merkezî yönetim stratejik öneme sahip zahirenin herhangi bir şekilde ülke dışına çıkarılmasına müsaade etmemişti. Merkezî yönetimin aldığı tedbirlere rağmen ehl-i örf ve ehl-i şer'den bazıları, zahire kaçakçıı̆ını limana yakın köylülerle anlaşarak

\footnotetext{
27 Harun Şahin, Klasik Dönem Osmanlı Ekonomisinde İktisadi Kontrol Araçları, Bartın Üniversitesi i.i..B.F. Dergisi, C. V, S. 10, 2014, 169.

${ }^{28}$ Mehmet Genç, Osmanlı İmparatorluğuna Devlet ve Ekonomi, Ötüken Yayınları, XI. Basım, İstanbul 2011, s. 41.

${ }^{29}$ Ahmet Tabakoğlu, Toplu Makaleler I iktisat Tarihi, Bayrak Matbaası, İstanbul 2005, s. 145.

${ }^{30}$ BOA MD 69, h. 469, s. 235.
}

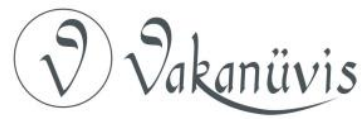


yapmışlardı. Keşan kadısına gönderilen hüküm de kazaya bağıı Erbince Limanına yakın köyler yaşayanların, limana gelerek kanuna aykırı bir şekilde Küffara zahire satarak suç işledikleri belirtilmişti. ${ }^{31}$ Merkezî yönetimin ürün fazlasının ambarlara konularak muhafaza edilmesi ve gerekli görüldügünnde kullanılması yönündeki emri, gerek devlet memurları (ehl-i örf ile ehl-i şer') gerekse köylüler tarafından ekonomik sebeplerden dolayı zaman zaman uyulmamıştı.

XVI. yüzyılın ikinci yarısında kırsal yerleşkelerin vergilendirilmesi ve alışılmış metotlarla üretimin sürdürülmeye çalışılması, Merkezî yönetimin zafiyetleri arasında yer almaktaydı. Bu durum ise köylerin viraneye dönmesine, tarımsal üretimin düşmesine ve devletin de en büyük gelir kalemleri arasında yer alan vergilerin azalmasına sebep olmuştu. Yani Merkezî yönetim, ürün fazlalığı yaşandığında köylüleri korumak için hayata geçireceği acil önlem planı olmadığı gibi ürün fazlası zahirenin stoklanması hususunda da bir plan dâhilinde hareket etmemişti.

\section{c) Tarım Alanlarına Zararlı Haşerelerin (Fare, Çekirge İstilası gibi) Zarar Vermesi}

Osmanlı köylüsü yaşanan iklimsel sorunlarının yanı sıra zararlı haşerelerle de mücaadele etmek zorunda kalmıştı. Osmanlı köylüsünü en çok mağdur eden, üretim sürecinde karşılaştığı ve baş etmek zorunda kaldığı fare sürüleri, tarım alanlarına girerek mahsule zarar vermekteydiler. ${ }^{32}$ Farelerin tarım alanlarına zarar vermelerinin yanı sıra çekirge sürülerin de tarım alanlarına girerek ürünlere zarar vermeleri, tarımsal ürünlerin hâsılatında düşüşlere yol açmıştı. Ekolojik sistem içerisinde çeşitli sebeplerle fare ve çekirge sayılarının artması ve bunların tarımsal faaliyetlere zarar vermesi, köylüler için ciddi tehdit oluşturmuştu. Kıbrıs Ada'sında yaşanan çekirge istilası nedeniyle kıtlık yaşanmıştı. ${ }^{33}$ iklimsel sebeplere bağı kuraklığın yaşandığı dönemlerde, köylülerin karşı karşıya kaldıkları bir başka sorun ise aşırı yağmurun yağmasından dolayı hâlihazırda bulunan sulardaki bakteri sayılarını

\footnotetext{
${ }^{31}$ BOA MD 69, h. 478, s. 240.

32 BOA MD 73, h. 602, s. 263

${ }^{33} \mathrm{BOA}$ MD 28, h. 104, s. 42.
}

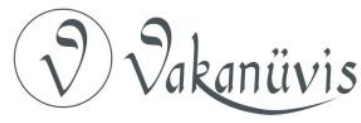


artırmaktaydı. Bakteri sayısının artmasına bağlı olarak tarımsal ürünlerde elde edilen rekolte düşmekteydi. ${ }^{34}$

Haşereler, doğrudan ürünlerde elde edilen verimi düşürdüğü gibi tarımsal arazinin verimini de düşüren başka bir faktör iklimsel nedenlere bağlı sellerin yaşanmasıydı. Seller nedeniyle toprak içerisinde bulunan kurtçuklar, su ile akıp gitmekteydi. Topraktaki kurtçuklar dışkılama yoluyla doğal gübre oluşturmaktaydılar. Sel yoluyla kurtçukların yok olması, toprağın gübre ihtiyacının karşılanamamasına sebep olmaktaydı. Gübresini alamayan toprakta ki ürünlerde ise verim kaybı yaşanmaktaydı. ${ }^{35}$

\section{d) Köylülerin Bir Çift Saban ile Ulaşım Araçlarını (Öküz, Deve, At ve Katır) Temin Edememeleri Nedeniyle Karşılaştıkları Sorunlar}

Klasik metotlarla yapılan tarımsal faaliyetin en önemli öğesi hiç şüphesiz bir çift saban ile öküz oluşturmaktaydı. Köylülerin, toprağı ekip biçmesinde ve harman yerindeki mahsulünü taşımasında “...tarımın traktörü saydığımız öküz..."36 tarımsal faaliyetlerin yerine getirilmesinde oldukça önemli bir yere sahipti. Köylülere zulüm eden gerek eşkıya gerek ise ehl-i örf ile ehl-i şer'den bazıları tarımsal faaliyetlerin en önemli aracı öküzleri, köylülerin elinden alarak mağdur etmişlerdi. Bu bağlamda Anadolu beylerbeyine gönderilen hükümde Bolvadin kadısının köylülerin öküzlerini elinde aldığı. ${ }^{37}$ gibi Kastamonu beyi ile Taşköprü ve Küre kadılarına gönderilen hüküm de Seralı köylülerinden İsa'nın bir çift öküzünü Sipahi Hızır'ın zorla alarak zulüm yaptığı belirtilmişti. ${ }^{38}$

XVI. yüzyılın ikinci yarısında tarımsal faaliyetlerin yerine getirilmesinde en önemli bir araç olan öküz gibi ulaşımda ve yük taşımada deve, at ile katır gündelik hayatta önemli bir yere sahipti. Bu sebeple köylere giderek yağma ve talanda bulunan bazı kötü niyetli devlet memurları ile eşkıyalar, köylülerin hem tarımsal faaliyetlerde hem de ulaşımda kullandıkları deve, at ve katırlarına el koyarak onları

\footnotetext{
${ }^{34}$ Zafer Karademir, a.g.e., s. 46.

35 Zafer Karademir, a.g.e., s. 66.

${ }^{36}$ Halil İnalcık, Köy, Köylü ve İmparatorluk, Osmanlı İktisat Tarihi, (Derleyen: Alaaddin Aköz), Selçuk Üniversitesi Fen Edebiyat Fakültesi Yayınları, Konya 2004, s. 371.

37 BOA MD 69, h. 52, s. 27.

${ }^{38}$ BOA MD 27, h. 780 , s. 327.
}

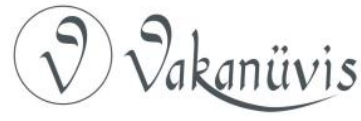


mağdur etmişlerdi. Bu husus hakkında Teke beyine gönderilen hüküm de Süleyman çavuşun otuz kadar eşkıya ile işbirliği yaparak köylere girdiği, köylülerin at ve katırları ile develerini zorla aldıkları belirtilmişti. ${ }^{39}$ Bunun gibi Antalya beyine gönderilen hüküm de Sipahi Mehmet'in yirmiden fazla eşkıya ile köylere giderek kendilerinin seferli olduklarını söyleyip köylülerin deve ve katırlarını zorla aldıkları belirtilmişti. ${ }^{40}$

Kara taşımacılığında devletin dâhili yerlerindeki tarımsal ürünlerin naklinde kağnı ve deve kervanları tercih edilmekteydi. ${ }^{41}$ Kara taşımacılığını aktif olarak kullanan köylülerin ulaşım araçlarına gerek ehl-i örf ile ehl-i şer' gerek ise eşkıyalar tarafından el konulması tarımsal faaliyetlerin sekteye uğramasına yol açmıştı.

Köylülerin Gündelik Hayatta Karşılaştığı Sorunlar

\section{a) Köy Yollarının Gelişmemiş OIması ile Köylüler/Köyler Arasında Yaşanan Arazi Sorunları}

Osmanlı Devleti yolların bakım ve onarımını bazı muâfiyetler vererek derbendci ve kaldırımcılara yaptırmıştı. ${ }^{42}$ Merkezî yönetim köy yollarının yapımı ve bozulan yolların tamir edilmesinde doğrudan işi yüklenen olmayıp yolun bakım ve onarımında köylüleri sorumlu tutmuştu. Bunun için bozulan yolların bakım ve onarımında sorumlu tutulan köylülere vergiler üzerinde kolaylıklar sağlanarak kamunun intiyacı yerinde alınan tedbirlerle sağlanmaktaydı. Bahşişler köylüleri, Vaki'han civarındaki bozulan yolların bakım ve onarımı ile vazifelendirilerek vergilerden muâf tutulması gerektiği ve ehl-i örfün vergiler hususunda köylülere zulüm yapmaması hakkında iç̧el -ili beyine emir verilmişti. ${ }^{43}$ Merkezî yönetim tarafından yolların bakım ve onarıma önem verilerek taşrada bulunan yetkililere yolların bakım ve onarımı sürecinde özellikle köylülere zulüm yapılmaması hakkında hükümler gönderilmişti.

\footnotetext{
39 BOA MD 73, h. 407, s. 87.

40 BOA MD 73, h. 369, s. 157.

${ }^{41}$ Sam White, a.g.e., s. 64.

42 Mehmet Ali Ünal, a.g.e., s. 150.

${ }^{43}$ BOA MD 72, h. 509, s. 259.
}

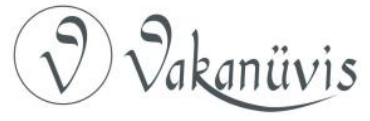


Tarımsal üretimin en önemli unsurları arasında arazilerin yer aldığı bilinmektedir. Köylüler arasında tartışmalara hatta zaman zaman çatışmalara yol açan tarla, mezra, yayla sorunları köyleri zaman zaman karşı karşıya getirmişti. Şöyle ki Cizre beyi Divâna mektup gönderip Hakkâri beyinin kendi sınırları içerisindeki yaylalar ile suları zapt ettiğini bu sebeple sınırdaş köylerde bir huzursuzluk yaşandığını arz etmişti. ${ }^{44}$ Bunun gibi Vize kadısına gönderilen hüküm de Rodoscuk kazasına bağlı Gazioğulları köy sınırına çeribaşıların girerek yerleştikleri ve köy sınırları içerisinde bulunan sığır çiftliğine sahiplenerek sorun çıkardıkları belirtilmişti. Bu sebeple yaşanan sınır sorunun kanuna göre çözüme kavuşturulması, köy sınırının tespit edilerek başkente gönderilmesi emredilmişti. ${ }^{45} \mathrm{Bu}$ bağlamda Manisa kadısına gönderilen hükümde de Hanı Beğ ile Melek (?) köy sınırları içine Zımmane (?) taifesinin yerleşmesinden dolayı sorun yaşandığı, yaşanan sorunun köyde güvenilen kişilerin şahadeti ile hak üzere çözüme kavuşturulması emredilmişti. ${ }^{46}$ Köy sınırlarının tahdit edilmesine rağmen kanuna aykırı davranılmasından dolayı köylüler arasında anlaşmazlıkların yaşandığı ve yaşanan anlaşmazlıklar Divâna yapılan arzlarla çözüme kavuşturulmaya çalışıldığı anlaşılmaktadır.

Osmanlının sınır boylarında bulunan köyler, yapılan savaşlardan dolayı mağdur olmuşlardı. Bu bağlamda Ohri beyinin Divâna gönderdiği arz-ı halde Alman harbi sebebiyle sınırda bulunan Gayri Müslim köylerden bazılarının isyan ederek Müslüman köylere saldırdıkları, köylülerin tarla, bağ ve bahçelerini yağmalayarak köylüleri dirlik veremeyecek hale düşürdüklerini belirtmişti. ${ }^{47}$ Bunun gibi sınır boylarında bulunan köylerin zarar gördüğüne dair Tımaşvar beylerbeyine gönderilen hüküm de Erdel vilayetine bağlı bazı köylerin mahsulâtına ve reâyâsına zarar verilmemesi emredilmişti. ${ }^{48}$ Erdel ve Tımaşvar, Osmanlı Devleti'ne bağlı eyaletler olmasına rağmen yanlışlıkla sınır köyleri düşman toprakları zannıyla vurulmuştu. Bu durumun Divâna arz edilmesi üzerine yanlışlığın giderilmesi yönünde Tımaşvar beyine hüküm gönderilmişti. Burada her halükarda sınır

\footnotetext{
44 BOA MD 26, h. 837, s. 289.

45 BOA MD 26, h. 894, s. 308.

${ }^{46}$ BOA MD 48, h. 358, s. 132.

47 BOA MD 27, h. 68 s. 23.

${ }^{48}$ BOA MD 48, h. 481 s. 172.
}

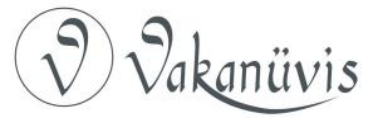


köylerinin yaşanan gerginlik ve çatışmalarda zarar gördüğü anlaşılmaktadır.

\section{b) Konar-Göçerlerin Tarım Arazilerine Zararları Sebebiyle Yaşanan Sorunlar}

Köylüler ile konar-göçerler, ehl-i örf ile ehl-i şer'in suiistimallerine maruz kalmalarına rağmen aralarında bir birliktelik kuramamışlardı. Bu durumun asıl sebebi ise köylüler ile konar-göçer Kürt aşiretleri arasında yaşanan sorunlarda göç yollarının takip edilmeyişi, Kürtlerin hayvanlarına otlatacak yer bulma endişeleri ile köyün ekinlik alanları olarak tabir edilen meraların usulsüz kullanılmasından yani bu iki grubun yaşayış şekilleri ile ihtiyaçlarının aynı doğrultuda olmayışından kaynaklanmıştı. ${ }^{49}$

Şöyle ki "...sürülerin mevsimlik hareketleri, otlaklara giden yollar ve bu yollar üzerinde yer alan bağ, bahçe ve tarlalar konusunda sürtüşmeler..." ${ }^{\prime 50}$ bu iki grubun ittifak yapmasına mani olmuştu. Hatta bu iki grup arasında zaman zaman yaşanan sorunlar, taşrada çözüme kavuşturulamadığından Divâna yansıtılmıştı. Genelde konar-göçerler hayvanlarını tarım arazilerine salarak yaymaktaydılar. Bunun gibi sürüden ayrılan hayvanlar ekili dikili tarım arazilerine girerek buralara zarar vermekteydiler. Bu olaylar iki grubu en çok karşı karşıya getirmekteydi. ${ }^{51}$ Şöyle ki Hamit sancağına bağı Kondanlu Yörüklerinin, köylülerin tarım alanlarına yerleşerek koyunlarını da ekinlerine salarak yedirmiş oldukları, hakkında köylülerin Divâna şikâyeti olmuştu. ${ }^{52}$ Köylülerin ürünlerinin yağma edilmesi hakkında ki bir başka hüküm ise Hayber Kalesi etrafında ki çiftçilerin zahire ve hurmalarının asi Arap Yahudileri tarafından yağma edildiği Divâna arz edilmişti. ${ }^{53}$ Köylülerin ekili dikili arazilerine konar-göçerler zarar verdikleri gibi zaman zaman harman yerlerini de ateşe vererek köylüleri mağdur edilmişlerdi. Bu bağlam da Saruhan beyi ile Biga kadısı köylülerin harmanlarının eşkıyalar tarafından ateşe verilmesinden dolayı köylülerin mağdur

\footnotetext{
49 Savaş Yılmaz, a.g.t., s. 109.

${ }^{50}$ Karen Barkey, Eşkıyalar ve Devlet Osmanlı Tarzı Devlet Merkezileşmesi, Çeviren:

Zeynep Altok, Tarih Vakfı Yurt Yayınları, II. Baskı İstanbul 2011, s. 119.

${ }^{51}$ Sam White, a.g.e., s. 113.

52 BOA MD 23, h. 157, s. 78.

53 BOA MD 23, h. 280, s. 103.
}

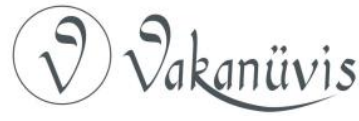


olduklarını arz etmişlerdi. ${ }^{54}$ Eşkıyaların kasıtlı bir şekilde köylülere zararlarının yanı sıra konar-göçerlerin de hayvanlarını otlatmak gibi sebeplerden köylülere zarar vermişlerdi. XVI. yüzyılın ikinci yarısında köylülerin, eşkıya zulmünden oldukça mağdur olmalarının yanı sıra konar-göçerlerle de sorunlar yaşamış olmaları ve tarım alanlarının çeşitli şekilde tahrip edilmesi, köylülerin üretimini olumsuz yönde etkilemişti.

Konar-göçerlerin çeşitli şekillerde köylülere zararlarının yanı sıra köylülerden bazıları da ekili dikili arazilere zarar vermişlerdi. Bosna beyine gönderilen hüküm de köylülerin tarım alanlarını ekip biçmeyerek boz bıraktıkları gibi tarım alanlarını meraya çevirip ot biçtikleri belirtilmişti. ${ }^{55}$ Merkezî yönetim tarafından tarım arazilerinin ekilip biçilmesine ve burada sağlanan doğrudan (tarım ürünleri) ile dolaylı (tarıma bağlı yapılan hayvancılık, bağcılık) faydaların süreklilik arz etmesine önem vermişti. Daha da önemlisi tarıma ve tarıma bağlı yan alanlarda elde edilen ürünler üzerinde alınan vergilerin inkıtaya uğramamasına Merkezî yönetim, azami ölçüde dikkat etmişti.

\section{c) Arazilerin Usulsüz Kullanımından Kaynaklanan Sorunlar}

XVI. yüzyılın ikinci yarısında eşkıyalar, taşrada kamu düzenini bozarak köylülere çeşitli zulümler yapmışlardı. Köylülerin canına, namusuna tecavüz eden eşkıyalar ${ }^{56}$, onların gelir kapısı olan mahsullerini ${ }^{57}$, zahire ve hurmalarını ${ }^{58}$ ve mal ve mülklerini ile yiyeceklerini ${ }^{59}$ yağmalayıp açlık ve kıtlıkla köylüleri baş başa bırakmışlardı. Şöyle ki Şam beylerbeyine gönderilen hüküm de Hayber Kalesi etrafında yaşayan çiftçilerin $\mathrm{Hacı}$ Arap Yahudilerinin zulmüne uğradıkları, çiftçilerin tarım alanlarına girerek yağma ve talanda bulundukları gibi kendi mülkleri olmayan topraklara yerleşerek ziraatta bulundukları, etrafta bulunan pınarların önlerine setler çekerek çiftçileri mağdur ettikleri belirtilmişti. ${ }^{60}$

\footnotetext{
54 BOA MD 27, h. 177 s. 62.

55 BOA MD 24, h. 89, s. 30.

${ }^{56}$ Savaş Yılmaz, a.g.t., s. 263.

57 BOA MD 23, h. 74, s. 37.

58 BOA MD 24, h. 280, s. 103.

${ }^{59}$ BOA MD 73, h. 73, s. 30.

60 BOA MD 24, h. 280, s. 103.
}

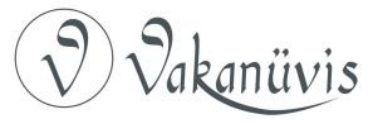


Bunun yanı sıra görevini kötüye kullanan ehl-i şer'den bazıları kanunsuz bir şekilde köylülerin uhdesinde olan yerlerin kullanımını başkalarına vermeleri nedeniyle de köylüler sorunlar yaşamıştı. Bu bağlamda Karaman beylerbeyine gönderilen hüküm de Karapınar ahalisinin kullanımında olan yaylaların, kadı tarafından şehirlilere onar akçe karşılığında kullanmaları için icazet verildiği bu sebeple köylülerin mağdur olduğu belirtilmişti. ${ }^{61}$ Bunun gibi İpsala ve Rodoscuk kadılarına gönderilen hükümde de vakıf mütevellisi Mehmet tarafından Divâna yapılan arzda, İpsala kazasına bağlı Bıyıklı ve Herağa köylerinin yaylalarında miriye ait sağmal koyunların gizliden otlatılarak vakıf köylerinin zarara uğratıldığı hakkında ki şikâyetinin incelenerek bu duruma son verilmesi gerektiği emredilmişti. ${ }^{62}$ Köylüler yaylalarını kanunsuz bir şekilde kullanılmasını ya da kullandırılmasını Divâna şikâyet ederek haklarını kanunen aramışlardı. Köylülerin şikâyetlerinde haklı olmalarında "...Osmanlı Imparatorluğu yaylalardan ve otlak kabul edilen yerlerden de vergi alırdı. Buralarda yayla yapıp ot ve sularında istifade edenler olursa güçleri nispetinde resim (vergi) öder..."63 kanun maddesinin bulunmasıydı. Bu kanun gereğince vergi karşııı̆ında yaylaları kullananların haricinde buraları kullanmamaları gerekirdi. Kanuna rağmen kadı görevini kötüye kullanarak köylüleri mağdur etmişti.

Köylülerin yaşamış oldukları sorunların bir kısmı köyün ardılında bulunan tahrir defterlerinde ekinlik ${ }^{64}$ yerler olarak belirtilen mezraların, kanunsuz bir şekilde köyün dışından gelenler tarafından kullanılmasından kaynaklanmıştı. Bu bağlamda mühimme defterlerindeki hükümlerin genelinden de anlaşılacağı üzere konargöçer şeklinde hayatını idame ettiren bazı Kürt aşiretleri ile yerleşik yaşam şeklini benimsemiş köylüler arasındaki huzursuzluk ve hatta yaşanan kavgaların çıkış nedeni Kürt aşiretlerinin, köylülerin meralarına girip buralara zarar vermeleri olmuştu. Bu bağlamda; Kayseri beyine ve kadısına gönderilen hüküm de Kayseri sancağına bağıı Göstere köylülerinden bazılarının, Divâna arz sunarak Kürt

\footnotetext{
61 BOA MD 23, h. 438 , s. 607.

62 BOA MD 71, h. 18 , s. 8.

${ }^{63}$ Sadık Albayrak, a.g.e., s. 96.

${ }^{64}$ Turan Gökçe, XVI. Yüzyılda Uşak Kazası, XIII. Türk Tarih Kongresi (Kongreye Sunulan Bildiriler), Cilt III., Kısım III., Ankara 1999, s. 1374.
}

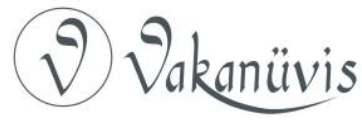


taifesinden Lek ve Avanik Cemaatlerinden; Husni, Şah, Alaçalı, Derviş Ali, Alican, Pir Ahmet gibi bazı kişilerin, Göstere köyüne ait meralara girerek zarar verdiklerinden, köylülerden bazıları bunlara mani olmak istediklerinde, köylülere küfür edip dayak attıkları bildirilmişti. ${ }^{65}$ Kanunda hayvanların ekili dikili arazilere girdirilmesi men edilmesi hakkında "...davar tahıla girse sahibine beş ağaç urub ağaç başına birer akçe cürüm alına ve eğer tahıla giren davarı öldürseler ıssına bahasın virdüreler. Amma cerime alınmaya tahıl ziyanın davarı ISSI ödeye..." ${ }^{\prime \prime 6}$ kanun maddesinin bulunmasına rağmen bu kanun maddesi çiğnenerek köylüler mağdur edilmişlerdi.

Köylülere ait yerlerin kanuna aykırı bir şekilde kullanımından kaynaklanan sorunlar olduğu gibi devlete ait yaylaların köylüler tarafından kullanılmasından da kaynaklanan sorunlar yaşanmıştı. Özellikle devlete ait otlakların yani yaylaların kullanımı devlet ile köylüler arasında sorunların çıkmasına sebep olmuştu. Şöyle ki Diyarbekir beylerbeyine gönderilen hüküm de Bozulus taifesinin Divâna sundukları arza binaen köylülerin yaylaları, tarıma açtıkları gibi burada bulunan su ve ottan da istifade ederek kendilerinin mağdur ettiklerini, miriye (devlete) ait yaylanın kullanımının etrafta bulunan köylere ait olmadığını, hayvanlarını otlatamadıkları için zarar gördüklerini arz etmişlerdi. ${ }^{67}$ Bunun gibi devlete ait korulukların köylüler tarafından kullanılmasından kaynaklanan sorunun çözümü hakkında Vize ve Silivri kadılarına gönderilen hüküm de Miri koruya, Görenler (?) köylülerinin yerleşerek korunun otunu biçip çayırlarını kullandıklar için devlete ait küçükbaş hayvanların otlatılmasında zorluklar yaşanmış olduğu ve bu sebeple korunun çayırlarının fuzuli yere zabt ettirilmemesi, köylülerin kanuna uymaları gerektiği belirtilmişti. ${ }^{68}$ Osmanlı Devleti bir taraftan köylülerin haklarını korurken diğer taraftan kamunun hakkını da koruyarak herhangi bir haksızlığa göz yummamıştı.

\footnotetext{
65 BOA MD 23, h.111, s. 53.

66 Ömer Lütfi Barkan, XV ve XVI ıncı Asırlarda Osmanlı İmparatorluğunda Ziraî Ekonominin Hukukî ve Malî Esasları, Kanunlar, Yayına Hazırlayan: Hüseyin Özdeğer, İstanbul Üniversitesi Rektörlük Yayınları, Cilt I, İstanbul 2001, s. 127.

67 BOA MD 24, h. 601, s. 225.

68 BOA MD 24, h. 842 s. 311.
}

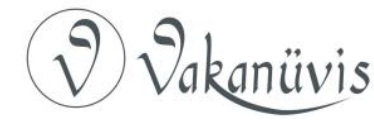


XVI. yüzyılın ikinci yarısında köylülerin sermayesi devletin belli şartlar altında verdiği araziler ile bir çift öküz ve saban oluşturmaktaydı. ${ }^{69}$ Osmanlı Devleti'nin merkez ile çeperinde bulunan eyaletlerdeki toprakların genelinin kurak ve dağlık olması, köylülerin intiyacı olan araç gereçlerin temininde de istenilen seviyede destekleyememesi ${ }^{70}$ köylülerin tarımsal faaliyetlerini yerine getirirken karşılaştıkları zorluklar arasında yer almıştır.

\section{Ehl-i Örf ile Ehl-i Şer'in Vergiler Üzerinde Köylülere Yaptıkları Zulümler \\ a) Ehl-i Örf ile Ehl-i Şer'in Görevlerini Kötüye Kullanıp Köylüleri İstismar Etmelerinden Kaynaklanan Sorunlar}

Taşraya çeşitli görevleri yerine getirmeleri için yetkilerle donatılarak gönderilen ehl-i örf ve ehl-i şer'den (devlet memurları) bazıları, görevlerini suiistimal ederek reâyâ ve berâyâya çeşitli haksızlıklar yapmışlardı. Bu durum (baskı ve haksızlıklar) köylüler tarafından divâna aralıksız bir şekilde arz edilerek yaşadıkları mağduriyetlere son verilmesini talep etmişlerdi. Devlet içerisine konuşlanmış kötü niyetli bazı ehl-i örf ve ehl-i şer'in (devlet memurları), köylüleri geçim kapısı olarak görmeleri, Divâna yapılan şikâyetlerde anlaşılmaktadır. Şöyle ki miri değirmene hizmet edenlerin kanunen vergiden muâf tutulmaları gerekirken mültezimler tarafından vergi alındığı gibi köprülerden geçenlerden de sekizer akçe alınmıştı. Bunun yanı sıra köylülere çeşitli angaryalar yükleyip bağ ve bahçelerindeki üzüm ve meyveleri taşıtıp, köylülerin çayırlarını hayvanlarına yedirmişlerdi. ${ }^{71}$ Bunun gibi ehl-i örfün kanuna aykırı davranarak köylülere angarya yüklemesi Vize kadısınca Divâna arz edilmişti. Kadı Divâna sunduğu arzda Istranca köylülerinin tekâlif vergisinden muaf tutulduklarına dair ellerinde emr-i şerif olmalarına rağmen subaşının, köylere bin çeki odun saldığını belirtmişti. ${ }^{72}$ Kanunla vaz' edilmiş yükümlülükler dışında köylülere angarya yükletilmesi suç olmasına rağmen görevini suiistimal eden ehli örf ile ehl-i şer'den bazıları kanuna aykırı davranarak keyfi uygulamalarda bulunmuşlardı. Bunların bu keyfilikleri köylüler

\footnotetext{
${ }^{69}$ Savaş Yılmaz, a.g.t., s. 60 .

70 Sam White, a.g.e., s. 101.

71 BOA MD 23, h. 80, s. 39.

72 BOA MD 70, h. 130, s. 61.
}

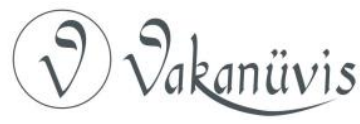


tarafından Divâna şikâyet edilerek haklarında adlî, idarî ve cezaî kararların çıkmasına sebep olmuşlardı. Şöyle ki Edirne kadısına gönderilen hükümde reâyâya saman salındığı ancak kiminde az kiminde çok saman alınarak haksızlık yapıldığı bu yüzden reâyânın rahatsız olduğu belirtilmişti. ${ }^{73}$ Merkezî yönetim tarafından kanunsuz ve adaletsiz bir şekilde reâyâya davranılmaması gerektiği taşradaki görevlilere emredilmişti. Bunun gibi köylülerden Baba Ahmet, Seferihisar Müderrisi Deli Kadı Mevlana Resul hakkında Divâna şikâyette bulunmuştu. Baba Ahmet, şikâyetinde kadı tarafından koyun sürüsüne el konularak mağdur edildiğini arz etmişti. ${ }^{74}$

Merkezî yönetim, kânunlarla ehl-i örf ve ehl-i şer' ile köylülere bazı haklar ve sorumluluklar yüklemişti. Malatya sancak kanununda da açıkça görüleceği üzere "...sancak beyleri ve subaşıları her yıl ot biçmeğe ve çeltük biçmeğe ve çeltüği davar ile ayıklatmağa şehirden ve kuradan eve bir adem sürüb on beş gün mikdarı ot ve çeltük biçtirüb ve taşıtdırub Müslümanları işlerinden koyub zulüm iderler imiş bid'at olduğı sebebden ref' olındı sancak beyleri ve subaşılar ot biçtirüb ve çeltük biçtirmek ve ayıklatmak hacetleri olıcak akçeler ile ırgad dutub biçtireler ayıklattıralar ve taşıtdıralar reâyâyı incitmeyeler. ${ }^{\prime 75}$ Kanun maddesi uyulması gereken kuralları belirtmesine rağmen bazı devlet memurları görevlerini suiistimal ederek köylüleri istismar etmişlerdi. Kânunnâmelerde sipahilere, köylülere tarım arazisinde hasat ettikleri ürünleri en yakın pazar yerine taşıtma hakkı verilmişti. Şöyle ki "...reaya taifesi (demetlerini) harman yerine getirip sipahi için döküvermek kanundur." 76 bu kanun maddesini kendi menfaatlerine kullanmak isteyen ehl-i örf ya da ehl-i şer'in, uzak yerlere yaptıkları ambarlara ürünleri köylülere taşıtarak zulüm yapmışlardı. ${ }^{77}$

Köylüler gerek beşeri nedenler gerekse doğal sebeplere bağlı olarak ekonomik zorluklarla karşılaşmışlardı. Bu bağlamda yaşadıkları ekonomik zorluklarda kurtulmak için de tefecilerde para almak

\footnotetext{
73 BOA MD 23, h. 305, s. 149.

74 BOA MD 24, h. 69, s. 23.

75 Ömer Lütfi Barkan, XV ve XVI ıncı Asırlarda Osmanlı İmparatorluğunda Ziraî Ekonominin Hukukî ve Malî Esasları, Kanunlar, s. 113.

${ }^{76}$ Sadık Albayrak, a.g.e., s. 195.

77 Savaş Yılmaz, a.g.t., s. 34.
}

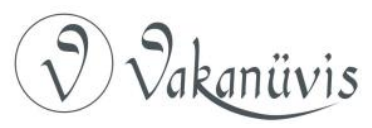


zorunda kalmışlardı. Kırçova'da İshak Bey Mescit İmamı Halil bey, köylülere aşırı miktarda faizle para vermiş. Zamanında faizi ödeyemeyen köylülerin ise malına el koymuş bundan dolayı köylüler yerlerini terk etmişlerdi. ${ }^{78}$ Köylülerin içerisine düştükleri ekonomik dar boğazda faydalanmaya çalışan kötü niyetli bir din adamının zulmü köylüler üzerinde menfi tesir bırakarak topraklarını terk etmelerine sebep olmuştu.

Ehl-i örf ve ehl-i şer'den bazıları köylüleri vergiler üzerinde suiistimal etmeleri köylerin boşalmasında, tarımsal rekoltenin düşmesinde buna bağlı olarakta sosyo-ekonomik sorunların artmasında etkili olmuşlardı. Köylülerden zamanında alınması gereken vergiler tahsildarlar tarafından alınmayarak başka bir zamana kasıtlı olarak bırakılıp daha sonra köylülere neden siz zamanında verginizi vermediniz diyerek cerime adı altında köylülerden fazladan vergiler almışlardı. Şam kadısına gönderilen hüküm de Tahsildarın Kenakir köylülerinden alması gereken yüz yirmi kırat buğdayı harman zamanından almayıp daha sonra köylülerden vergileri tahsil etmek isteyip zulüm yaptığı belirtilmişti. ${ }^{79}$ Harman zamanında mahsulün vergisini çok rahat ödeyebilecek durumda olan köylülerden vergiler kasıtlı alınmayarak köylülerin hem aynî hem de nakdî yönden darlık zamanında vergiler tahsil edilmek istenmişti. Vergileri ödemekten zorlanan köylülere zamanında vergileri ödemedikleri için de tahsildarlar cerime adı altında vergiler alarak köylüleri mağdur etmişlerdi. Yine bu husus hakkında Bağdat Beylerbeyi ile kadısına gönderilen hükümde Cesan Bedre ile subaşılarının reâyâda aynî almaları gereken vergileri zamanında almayarak başka bir zamana bıraktıkları ve reâyâdan fahiş oranda vergi aldıkları, reâyâ tarafından Divâna arz edildiği belirtilmişti. ${ }^{80}$ Kanunda verginin zamanında alınmasına yönelik "...reayanın harmanların kesdüklerinde öşürlerin üzerlerinde koyub zaman geçirüb sonra narh-ı rûzîden ziyâde akçeler alurlar imiş ...Bid'at olduğı sebebden ref' olundı ... Ve öşürlerin dahi reaya üzerinde koyub akçe almayalar heman kesdükleri gibi

\footnotetext{
78 BOA MD 24, h. 72, s. 24.

79 BOA MD 68, h. 51, s. 26.

80 BOA MD 23, h. 185, s. 391.
}

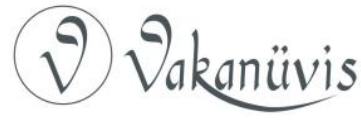


anbarlarına dökeler. ${ }^{\prime 11}$ kanun maddesinin bulunmasına rağmen bazı devlet memurları kasıtlı olarak fazladan vergi almak için vergiyi zamanında almamışlardı. Tahsildarların, köylülerden almaları gereken vergilerin fazla alındığı Divâna şikâyet edilerek yapılan haksızlığa son verilmesi hakkında Hırsova kadısına gönderilen hükümde de anlaşılmaktadır. Şöyle ki tahsildarların, köylülerden alması gereken öşürü fazladan alarak köylüleri mağdur edildiği belirtilmişti. ${ }^{82}$ Bunun gibi Semendre beyine gönderilen hüküm de tahsildarların, âdatı ağnam vergisini kanuna aykırı bir şekilde fahiş oranda topladıkları gibi defterde düşülmesi gereken; satılmış, hastalanmış ya da ölen hayvanlar üzerinden de köylülerden vergiler alarak köylüleri mağdur ettikleri belirtilmişti. Tahsildarların yapmış oldukları bu haksızlıklarının yanı sıra kanuna göre otuz beşer akçe almaları gereken haraç vergisinin de yetmiş ile seksener akçe topladıkları bu sebeple köylülerin yerlerini terk ederek köyün viraneye döndüğü açıklanmıştı. ${ }^{83}$

Köylülerin üretimde oldukça gayretli ve üretken oldukları dönemde ehl-i şer' ve ehl-i örfün görevlerini kötüye kullanmaları oldukça düşündürücüdür. Şahsi çıkarlarını ön plana alarak haksız mal toplayıp zengin olmak isteyen bazı devlet memurları, üretici kesim olan köylülere baskı kurup zulüm yapmalarında, köylüleri geçim kapısı olarak görmeleri etkili olmuştu. Özellikle III. Murat döneminde yaşanan malî buhranlar ${ }^{84}$, ehl-i örf ile ehl-i şer'in görevlerinde suiistimallere varan haksızlıklar yapmasında etkili olmuştu. Şöyle ki tahsildarlar topladıkları vergilerin tamamını devlet hazinesine teslim etmiyorlardı. Köylülerden çeşitli şekillerde aldıkları zamlı vergileri de (cerime cezası) tahsildarlar hazineye teslim etmeyerek zimmetlerine geçirmişlerdi. Bunun neticesinde ağır vergiler altında ezilen Osmanlı köylüsü tarlasını, bağını terk etmiş, üretim düşmüş buna bağıı olarak da köyler yaşanmaz hale gelerek viraneye dönmüş, kırsaldan şehirlere doğru göçler yaşanmıştı.

81 Ömer Lütfi Barkan, XV ve XVI ıncı Asırlarda Osmanlı İmparatorluğunda Ziraî Ekonominin Hukukî ve Malî Esasları, Kanunlar, s. 114.

82 BOA MD 23, h. 470 , s. 622.

${ }^{83}$ BOA MD 26, h. 228, s. 87.

${ }^{84}$ Nurullah Karta, "Kuruluştan Tanzimat'a Osmanlı İmparatorluğu'nda Para Kredi ve Faiz Politikaları Üzerine Bir Değerlendirme”, Jasss, Sayı: 69, 2018, ss. 381-395., s. 393.

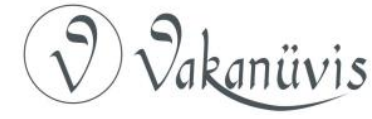




\section{b) Ehl-i Örf ile Ehl-i Şer'in Köylülerin Ürünlerini Satmalarında Zorluklar Çıkartmasından Kaynaklanan Sorunlar}

Merkezî yönetim, taşradaki ehl-i örf ile ehl-i şer'e bazı yetki ve sorumluklar vererek görevlendirmişti. Yetki ve sorumluluklara haiz olan ehl-i örf ile ehl-i şer'den bazıları görevlerini suiistimal ederek köylülere zulüm yapmışlardı. Yapılan haksızlıklara razı olmayan köylüler arzlarını Divâna sunarak haksızlıkların giderilmesini talep etmişlerdi. Şöyle ki İznikmid, Sapanca, Bolu ve Kurşunlu havalisine ticaret yapmak için köylere giden tüccarlara, kadılar tarafından mani olunmak istendiği, köylülerin ise ürünlerini tüccarlara belirlenen fiyatta satmak istemelerine rağmen bunların engellendikleri, köylüler tarafından Divâna arz edilerek bu haksızlığa mani olunması talebinde bulunmuşlardı. ${ }^{85}$ Gerek ehl-i örfün gerek ise ehl-i şer'in, köylülere ürünlerini sattırmak istemeyişlerinde kendi çıkarlarını düşünmeleri etkili olmuştu. Bu hususta Vulçıtrın'a bağlı köylerde ki ekinlere kadılarca el konulmuş. Bu şekilde köylüler haksızlığa uğratılmıştı. ${ }^{86}$ Adeta köylülerin bir geçim kapısı gibi görünmesi ${ }^{87}$, tarım alanlarının terk edilmesinde oldukça etkili olmuştu. Böylece tarımsal üretim düşmüş, köyler viraneye dönmüştü.

Köylüler, ürünlerini hasat edip köprüden geçmek istedikleri zaman tahsildarların kendilerinden kanunsuz olarak akçe aldıklarını Divâna şikâyet etmişlerdi. ${ }^{88}$ Köy yerlerinde bağ veya tarlalarda ürünlerini hasat eden köylülerin kaza yerlerine gidip ürünlerini satmak istemeleri bazı kötü niyetli ehl-i örf tarafından engellenmişti. Bu durumun asıl sebebi ise köylülerin ürünlerine çeşitli gerekçelerle el koyarak haksız kazanç sağlamak istemeleriydi. Köylüler bir taraftan görevini kötüye kullanan bazı devlet memurlarının zulmü altında baskı görürken diğer taraftan da devlete nakdi olarak ödemek zorunda oldukları vergileri vermeleri için ürünlerini satmak zorundaydılar. ${ }^{89} \mathrm{Bu}$ hususta köylüler çeşitli zorluklarla karşılaşmışlardı. Şöyle ki köylüler ürünlerini kazalara satmaya götürdüklerinde pazar yerinde darp edilerek dövülmüşlerdi.

\footnotetext{
85 BOA MD 27, h. 867, s. 363.

${ }^{86}$ BOA MD 27, h. 906 , s. 378.

87 Savaş Yılmaz, a.g.t., s. 241.

88 BOA MD 23, h. 80, s. 39.

89 Huricihan İslamoğlu, a.g.e., 91.
}

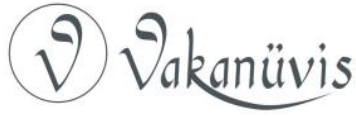


Bu husus hakkında Larende ve Gafiryad kadısına gönderilen hüküm de Larende'ye yakın (?) bir köyde mahsulünü pazara götüren köylünün, nahiye halkından birisi tarafından dövüldüğü ve bu olayın nahiye halkı ile köylüleri karşı karşıya getirdiği belirtilmişti. Olayın uzaması neticesinde subaşı tarafından köylülerin ihtiyaçlarını karşılamak için nahiye pazarına gidip alış veriş yapmalarına mani olunduğu bu sebeple köylülerin mağdur edildiği, yaşanan mağduriyetin ortadan kaldırıması emredilmişti. ${ }^{90}$

Üretim ve arzda önemli bir yere sahip köylüler sistem içerisinde kolektif bir yapıya sahip olmayışlarından dolayı ürünlerini pazar yerlerine götürüp satmalarında bazı sorunlarla mücadele etmek zorunda kalmışlardı. Köylülerin gerek ürünlerini pazarlamalarında gerek ise ulaşımda sorunlar yaşamalarının iki ana sebebi bulunmaktaydı. Bunlardan birincisi ulaşım imkânlarının zor ve pahalı olması iken ikincisi ürünlerin pazarda satılması için köylülerin ellerinde yeterince sermayelerinin olmayışıydı. ${ }^{91} \mathrm{Her}$ ne kadar XVI. yüzyılda gerek kentlerde gerekse ise kır yerleşkelerinde paranın kullanımında zorluklar ${ }^{92}$ olmasa da köylülerin ellerindeki ürünleri pazarlayacak ana sermayeleri bulunmamaktaydı.

Yukarıda bahsedildiği gibi gerek ehl-i örfün gerek ise ehl-i şer'in, köylülerin ürünlerini satmalarında zorluklar çıkarmaları; kentten köylere doğru para akışının inkıtaya uğramasına da sebep olmuştu.

\section{Merkezi Yönetimin Köylülerin Sorunlarına Karşı Aldığı Tedbirler}

Merkezi yönetimce, köylülerin ve köy hayatının devamı oldukça önemliydi. Osmanlı Devleti, tebaanın herhangi bir kıtlıkla karşılaşmaması için tarımsal üretime oldukça önem vermişti. Bu bağlamda "vazifesi ibâdullâhın terfîh-i ahvâli olan bir devlet" ${ }^{93}$ ciddi tedbirler alarak tebaasının mağdur olmaması için mücaadele etmek zorundaydı. Bunun yanı sıra XVI. yüzyılın ikinci yarısında devletin en önemli gelir kalemleri arasında yer alan tarımsal alanda elde edilen

\footnotetext{
90 BOA MD 57, h. 375, s. 143.

91 Mehmet Genç, a.g.e., s. 46.

92 Şevket Pamuk, Osmanlı Ekonomisi ve Kurumları I, Türkiye İş Bankası Kültür Yayınları, IV. Baskı, İstanbul 2013, s. 26.

93 Hasan F. Yılmaz, a.g.e., s. 116
} 
aynî ve nakdî vergiler gelmekteydi. Bu bağlamda Merkezî yönetim, reâyânın taşradan, Divâna sundukları arzlara binaen derhal tetkikat başlanması için ilgili yerin ehl-i örf ya da ehl-i şer'ine fermanlar, beratlar gönderip köylülerin zulme uğramaması için en üst seviyede önlemler alınmasını emretmişti. Bu bağlamda görevlerini suiistimal edenlere karşı idarî, malî gibi cezalar verilmişti. Bu durumu Divân-ı hümâyûndan taşraya gönderilen hükümlerin son kısımlarında yer alan, yasaklara uymayanların isimlerinin yazılıp gönderilmesi ${ }^{94}$ ibaresinde görmekteyiz. Bu hususta Konik yaylasında reâyâ ve berâyânın huzurunu bozup canına, malına ve ırzına tecavüz edenlerin yakalanıp bu mücrimlerin haklarından gelinmesi için kadıya gönderilen hüküm dikkat çekmektedir. Hükümde fesat ve şenaatı tespit edilenlerin derhal yakalanarak haklarından kanunen gelinmesi emredilmişti. ${ }^{95}$ Anadolu beylerbeyine gönderilen hüküm de ise ... ceza u sezaları viresin. Bu hususta tamam-ı hakk üzre olup ehl-i fesada himayet olunmaktan kendu hallerinde olanlara dahl olunmaktan hazer eyleyesin. ${ }^{96}$ ve ... muktezayı şerî şerif üzre haklarından geldirüb ihmal u ihmal olunmağla ehl-i fesad ruhsat bulub kimesnenin malına ve canına zarar iriştirmekten hazer eyleyesin ${ }^{97}$ denilerek suçları tespit edilenlere hak ettikleri cezaların verilmesi ve suçluların korunmaması gerektiği üzerinde özellikle durulduğu görülmektedir. Bunun yanı sıra masum insanlara dokunulmaması gerektiği, kamu düzenini bozanların korunup kollanmamasına, taşradaki görevlilere emredilerek reâyânın can, mal ve namus güvenliğinin sağlanmasına önem verilmişti.

Ehl-i örf ya da ehl-i şer' tarafından İstanbul'un zahire ya da et ihtiyacının karşılanması hususunda köylülere zulüm yapıldığı Divâna şikâyet edilmesi üzerine; “...Vilayeti Anadolu kadılarına gönderilen hüküm de koyun vesair zahire almağa varıb akçe ile narh-ı ruzı zahire ve koyun almalu olduklarında hılaf-ı şerî kimesne-i dahl ittirmeyub..."98 denilerek i̇stanbul'un ihtiyacı zahire ya da et ihtiyacının karşılanırken bu bahane ile köylülere zulüm yapılmaması gerektiği, alınan yiyeceklerin günlük bedeli neyse o fiyat üzere fiyatlandırımasına dikkat

\footnotetext{
94 BOA MD 23, h. 80, s. 39.

95 BOA MD 23, h. 86, s. 42.

96 BOA MD 23, h. 136, s. 65.

${ }^{97}$ BOA MD 23, h. 259, s. 128.

98 BOA MD 24, h. 600, s. 225.
}

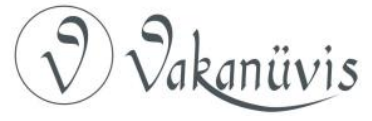


edilmesi ve köylülerin mağdur edilmemesi üzerinde durulmuştu. Bunun gibi Merkezî yönetim, taşradaki ehl-i örf ile ehl-i şer' tarafından yapılan haksızlıklara karşı da ikaz mahiyetinde hükümler sadır etmişti. Bu bağlamda Divâna, köylüler arzlar sunarak özel mallarına ehl-i örfün el koyarak mağdur edildiklerini arz etmişlerdi. Şöyle ki Karahisar-ı Sahib ve Sefer-i Hisar kadılarına gönderilen hüküm de köylülerin ellerinde mülknâme ile vakıfnâme olmasına rağmen sipahi ve hisar erleri tarafından mal ve mülklerine el konulduğunu, bu şekilde kendilerinin mağdur edildiklerini divâna arz ettikleri belirtilmişti. Bu husus hakkında köylülere ait bağ, bahçe ile mülklere kanun gereğince dokunulmaması gerektiği ve emri dinlemeyenlerin isimlerinin yazılıp başkente gönderilmesi emredilmişti. ${ }^{99}$ Kanuna aykırı davranıp köylülerin taşınır taşınmaz mal ve mülküne el koyanlar hakkında gerekli adlî işlemler yapılarak haklarından gelinmişti.

Merkezî yönetim sınırdaş köyler arasında yaşanan sınır sorunlarının Divân-ı hümâyûna, köylülerin arz etmeleri nedeniyle köy sınırlarının tespitinde oldukça dikkatli davranılması gerektiğini taşradaki görevlilere emretmişti. Bu bağlamda köy sınırlarını belirleyen alâmetlerin yeniden dikilip bozulan köy sınırlarının belirlenmesine ve o köylerde yaşayan güvenilir insanlardan bazılarına müracaat edilerek bilirkişi olarak görüşlerinin alınmasına, taşradaki gerek ehl-i şer'e gerekse ehl-i örfe belirtmişti. ${ }^{100}$ iki sınırdaş köy arasında yaşanan, sınır sorunun çözümünde köylerdeki güvenilir insanlara iki köy arasında eski sınırın nerede olduğunun sorulmasında, Merkezî yönetimin, reâyânın/köylünün görüşünü alınmasını istemesinde köyler arasında bozulan sınırların tespitinde sorumlu devlet memurlarının herhangi bir suiistimal yapmalarını engellemek istemesi etkili olmuştur. Aynı zamanda da bu uygulamayla Merkezî yönetim, köylülerin şahadetine önem verildiğini göstermiştir.

Köy sınırlarının belirlenmesine oldukça önem veren Merkezî yönetim, taşradaki ehl-i şer' ile ehl-i örfe gönderdiği hükümlerde, kamu huzur ve güvenliğini bozanlara ağır cezalar verilmesini de emretmişti. Verilen cezalar arasında da bazen sürgün cezaları yer almıştı. Bu bağlamda "...ehl-i fesadların kayd u tebdil Kıbrıs'a gönderesin ve teslim

99 BOA MD 24, h. 643, s. 242.

100 BOA MD 48, h. 930, s. 314.

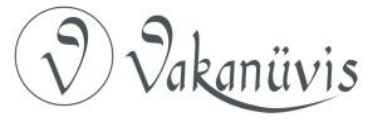


olduğuna temessük idub dergâh-ı muallâma gönderesun. ${ }^{101}$ denilerek suçlulara sürgün cezası verilmiştir. Merkezî yönetim sadece suçlulara sürgün cezası vermeyip aynı zamanda suçluların aileleriyle sürgüne tabii tutarak ağır cezalar vermişti. Şöyle ki "...reâyâya zulm u teaddileri olduğu vakî ise tayfe-i mezburenin bellu başlu olan ehl-i fesadı ele getürüb ehl-ü iyalleriyle yarar ademlere koşub Kıbrısa sürgün idüb"102 şeklindeki ceza, sürgün cezasının geniş kapsamlı tutulduğunu göstermektedir.

Yukarıdan da anlaşılacağı üzere Merkezî yönetimce, reâyâya/köylülere haksızlık yapanlar, adil bir yargılamanın ardında suçları kesinleşmiş ise çeşitli cezalara çaptırılmışlardı. Şöyle ki idarî ve malî cezalar da verilerek suçlular, devlet kapısından uzaklaştırılmıştı. Bu bağlamda Anadolu beylerbeyine gönderilen hüküm de "...mezkurun çavuşluk gedügünün ahire tevcih idü ${ }^{\prime 103}$ şeklindeki ifade de görevini kötüye kullanan ehl-i örfe idarî cezanın verildiği anlaşılmaktadır. Burada sadece idarî ceza verilmekle kalınmamış, suçluya aynı zamanda malî ceza da verilmiştir. Çünkü görevini suiistimal ederek kaybeden devlet memuru elde ettiği bütün idarî ve malî kazançları da kaybetmekteydi. Bu bağlamda “...kemâkân niyabetden ref' idüb min $b a^{\prime} d$ kısmete vesair davaya ... dahl itdirmeyesin..."104 hükmü verilerek naibin görevine son verildiği ve davalarda elde ettiği gelirlerini de kaybettiği anlaşılmaktadır.

Osmanlı Devleti, kanunnamelerle tebaa ve devlet memurlarının (ehl-i örf ile ehl-i şer') uyması gereken kuralları belirleyerek kamu düzenini sağlamaya çalışmıştı. Bu hususta Merkezî yönetim, köylülerin arz/şikâyetlerine binaen yaptırmış olduğu teftiş ve tahkikat neticesinde suçları kesinleşenlere derhal idarî, malî cezalar vererek haksızlıkların önüne geçmeye çalışmıştı. Merkezî yönetim, kanun gücüyle almış olduğu bu önlemlerin yanı sıra köylülerin sorunlarının çözüme kavuşturmak için amme hizmetlerini de yerine getirmek için gayret sarf etmişti.

\footnotetext{
101 BOA MD 23, h. 111, s. 53.

102 BOA MD 23, h. 389, s. 184.

103 BOA MD 23, h. 166, s. 82.

104 BOA MD 23, h. 470, s. 622.
}

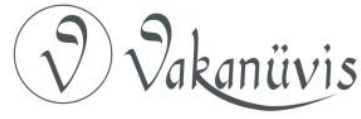


Merkezî yönetim özellikle kırsalda yaşanan su sorunlarının çözüme kavuşturulması için su yataklarının temizlenmesi ve köprülerin bakım ve onarımın yapılmasına oldukça dikkat etmişti. Bu bağlamda Drama kadısına gönderilen hüküm de Karasu Yenicesi köprüsünün tamir edilmiş olduğunu ancak köprünün gözlerinin kum ve ağaç kütükleriyle kapanması sebebiyle buraların temizlenmesini ve bu hizmet için iki kişinin görevlendirilmesini, böylece suyun yok yere heba olmasına mani olunarak reâyânın istifadesine sunulmasını emretmişti. ${ }^{105}$

Merkezî yönetim, köylülerin tarımsal faaliyetlerinde tarımsal rekoltenin düşmesinde iklimsel koşullar gibi etkili olan haşerelerle mücadelede de bazı önemler almıştı. Özellikle çekirge istilasına karşı çekirge yumurtalarının yakılmasını, çekirgeyle beslenen kuşların, çekirge istilasında $\mathrm{ki}$ yerlere gönderilmesini, çekirge suyunun kullanılmasını sağlamıştı. ${ }^{106}$ Ancak alınan bu önlemler oldukça sınırlı kaldığı için köylülerin rekolte kayıplarına mani olunamamıştı.

Köylülerin gündelik hayatta karşılaştıkları sorunlara çözümler arandığı gibi kötü niyetli köylülerden bazılarının suiistimallerine karşı da Merkezî yönetimce önlemler alınmıştı. Osmanlı Devlet'inin tarım politikasının nirengi noktasını tarım alanlarının ekilip biçilmesi ile bu yerlerin denetimi oluşturmaktaydı. Bu sebeple topraklarını ekip biçmeyen köylülere, devletin yaptırımları ağır hükümler taşımaktaydı. Bu şekilde Merkezî yönetim, hem vergiler yoluyla kazancının devam ettirmeyi amaçlamış hem de tarımsal üretimin devamını sağlayarak herhangi bir darlığın/kıtlı̆̆ın yaşanmasına mani olmayı amaçlamıştı. Bu bağlamda Bosna beyine gönderilen hüküm de "...reâyâ ola kadimden ziraat olunur yerleri çayır koduklarında sipahi mağrifeti ile komuyub ziraat olunurken üç yıl alettevalî bila mani boz ve hali komuşlar ise sipahinin mahsuline gadr eyledikleri ecilden ol asiler tapuya mustehak olur." 107 burada köylülerin tarımsal üretimde bulunmasının belli şartlara bağlı olduğu ve toprağını üç yıl ekip biçmeyenlerin topraklarının alınacağı belirtilmektedir. Yani Merkezî yönetim gelirlerinin azalmaması ve köylülerin asude-i halde kalıp üretime devam etmelerini sağlamaya çalışmıştı. Bu bağlamda Budun'da ki Vezir

\footnotetext{
105 BOA MD 23, h. 310, s. 150.

106 Zafer Karademir, a.g.e.,76.

107 BOA MD 24, h. 89, s. 30.
}

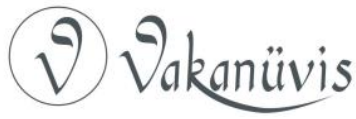


Mustafa'ya gönderilen hüküm de “...Havassı hümayun varoşlarında ve köylerin ber vechi iltizam umena ve ummal zabt idub zulm u teaddilerinden reâyâ peymal u perakende olup niçe köyler ve varoşlar harab kalub cizyeye noksan..."108 ibaresinde tahsildarların zulmünden köylülerin yerlerini terk ederek üretimde bulunmadığı bu sebeple devlet hazinesinin gelirlerinde bir kayıp olduğu açıklanmaktadır. Tahsildarlar hakkında Divâna yapılan sayısız şikâyetlere binaen Merkezî yönetim vergilerin kanunla belirlenen oranda köylülerden alınmasını, "...kanun üzre mevacib alınub ziyade bri akçe alınmayub alunduğı takdirce ziyadesi ashabına redd olunmasın." 109 emrederek tahsildarların görevlerini kötüye kullanmamalarına dikkat çekmiştir. Bu şekilde Merkezî yönetim, köylülerin herhangi bir suiistimale uğramalarını önlemeye çalışmıştı. Nihayetinde adlî, malî ve cezaî tedbirlerle üretimin mihenk taşını oluşturan köylülerin arzları dikkate alınmıştı. Böylece üretimin en önemli sacayağını oluşturan köylerin huzurla üretime devam etmeleri sağlanmaya çalışılmıştı.

Köylülerin kaza yerlerinde karşılaştıkları olumsuzlukları önlemek için bazen köy yerlerinde de pazarların kurulmasına izin verilmişti. Bu şekilde hem köy ekonomisinin canlanması sağlanmış hem de köylüler ile şehirliler arasında ortaya çıkacak sorunlar çok aza indirilmek istenmişti. Bu bağlamda köylüler elde ettikleri ürünleri satmak için sadece kaza ve nahiyelere gitmek zorunda kalmamışlardı. Huricihan İslamoğlu Karahisar-ı Demirli nahiyesine bağlı bir köyde, pazar vergisinin alındığını belirterek. ${ }^{110}$ köy yerlerinde pazarların kurulduğunu bu şekilde ticaretin yerelde canlandırılmaya çalışıldığını ve pazar kurulan yerler ile civarındaki köylülerin ihtiyaçları yerinde sağlanarak köylülerin nakit ihtiyacının karşılandığını belirtmişti.

Köylüler, gerek beşerî gerek ise doğal sebeplere bağlı sorunlar yaşadıklarında taşranın çeşitli nedenlerle sorunlarını çözememeleri halinde sığınma kapısı olarak devletin en yüksek yasama, yürütme ve yargı erkini elinde tutan Divâna müracaat ederek haklarını arayıp mağduriyetlerinin giderilmesini istemişlerdi. Bu bağlamda Merkezî yönetim, köylüsünü gerek ehl-i örf gerekse ehl-i şer'in herhangi bir

\footnotetext{
108 BOA MD 26, h. 292, s. 114.

109 BOA MD 70, h. 30, s. 18.

110 Huricihan İslamoğlu, a.g.e., 236-237.
}

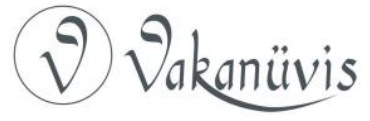


suiistimallerine karşı korumuş, ${ }^{111}$ adaletle yönetip güvenliğini sağlamaya çalışmıştı. ${ }^{112}$ iklimsel koşullara bağlı yaşanan sorunlara karşı da köylülere tohumluk yardımı, vergi affı gibi kolaylıklar sağlanmıştı.

Tarımsal alanda yaşanacak üretim ile tüketim arasındaki bir dengesizliğin yaşanması ise darlığın ya da kıtlığın yaşanmasına yol açmaktaydı ${ }^{113}$. Bu sebeple üretimin nirengi noktasında bulunan köylülerin hakları ve korunması kânunnâmelerle garanti altına almıştı. ${ }^{114}$. Merkezî yönetimin teftiş, tahkikat yetkisini kullanarak taşrada yapılan arzları bir karara bağlamıştı. Buna rağmen devletin kendisi bizzat üretimin içerisinde olmayıp üretim ile tüketimin kontrolünü yapmıştı. ${ }^{115}$ Devletin teftiş ve denetim mekanizmasını işler halde tutmasının yanı sıra köylülerin sistemli ve örgütlü bir yapıya sahip olmayışları tarımsal alanda sorunların sürüp gitmesine sebep olmuştu. ${ }^{116}$

\section{Sonuç}

Osmanlı sosyo-ekonomik yapısının belirlenmesinde önemli bir yere sahip olan köylüler, üretimden pazara kadar geçen süreçte bazı zorluklarla karşılaşmışlardı. XVI. yüzyııın ikinci yarısında tarım ve tarıma bağlı iş kolları ekonomik hayatta ciddi bir güç oluşturmuştu. Tarım temelli bir ekonomik yapıya sahip olan ve nüfusunun büyük bir çoğunluğu köylerde yaşayan, Osmanlı Devleti'nde tarım alanlarının kontrol edilmesi elzem olmuştu. Tarımsal faaliyetlerin merkezinde yer alan reâyâ/köylü, tohumu toprakla buluşturduğu andan itibaren gerek iklimsel faktörlerden gerekse beşerî nedenlerden kaynaklanan bazı olumsuzluklarla mücadele etmek zorunda kalmıştı.

Köylülerin elde edecekleri ürünler üzerinde ne zaman ve ne oranda vergi ödeyecekleri kanunla belirlenmişti. Devletin alacağı vergilerin haricinde bazı işgüzar devlet memurlarının (ehl-i örf ile ehl-i şer'), ikinci bir vergi toplayıc olarak keselerini doldurmaları yani yasal olmayan yollarla vergiler almaları, köylüleri tarımsal üretimde çıkmaza

\footnotetext{
111 Karen Barkey, a.g.e., s.28.

112 Sam White, a.g.e., s. 71.

113 Mehmet Genç, a.g.e., s. 59.

${ }^{114}$ Sam White, a.g.e., s. 73.

115 Zafer Karademir, a.g.e., 28.

116 Karen Barkey, a.g.e., s.45.
}

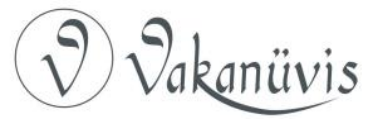


sokmuştu. Devlet memurlarının yanı sıra köylülerin, eşkıyalar ve konargöçerlerle de sorunlar yaşamaları, köylerde üretim sürecinin sorunlu olmasına yol açtığı gibi üretim üzerinde güvenliğin ne denli belirleyici olduğunu da ortaya koymaktadır.

Osmanlı köylülerinin belirli topraklar üzerinde bir çift öküz ve sabanla yapmış olduğu tarımsal faaliyetlerini hiç kuşkusuz belirleyen ana faktör ise iklimsel (kuraklık, sel gibi) koşullar oluşturmuştu. Köylü ailelerinin atadan kalma, doğma öğretilerle tarım arazilerini ekip biçmeleri, kendilerini ve kullandıkları tarım araç ve gereçlerini geliştirememeleri, hasat zamanında beklenen hâsılatı alamamalarına sebep olmuştu. Ayrıca köylüler arasında bir birliktelik de bulunmamaktaydı. Bütün bunlar Osmanlı Devleti'nde tarım arazileri üzerinde istenilen oranda ürün alınmasına mani olmuştu.

Osmanlı Devleti, köylülerin gerek iklimsel faktörlerden gerekse beşerî nedenlerden kaynaklanan sorunlarına, Divâna yapılan arzlara binaen çözüm yolları aramıştı. Çünkü Osmanlı malî yapısının nirengi noktasını tarım arazilerinden aldığı vergiler oluşturmaktaydı. Bu sebeple toprakların ekilip biçilmesine oldukça önem vermişti. Merkezî yönetim vergilendirilen köylülerin, topraktan kopmamaları, köylerin viraneye dönmemesi için özellikle çaba sarf etmişti. Bu bağlamda tahsildarların, kanunun vaz' ettiği şekilde vergileri tahsil etmelerini teftiş ettirerek köylülere haksızlık yapıımasını önlemeye çalışmıştı. Alınan önlemlere rağmen tahsildarların görevlerini suiistimal edip köylüleri gelir kapısı olarak görmelerine tam anlamıyla mani olunamamıştı.

Merkezî yönetimin tarım alanlarının ekilip biçilmesine, köy hayatının sürmesi ile vergi konusundaki hassasiyetinin, köylülerin bir dönüm arazide elde edecekleri ürün miktarını artırılmasına yönelik ciddi bir çalışmalar ile köylülerin yapısal sorunlarına çareler bulunmaya yönelik olmayışı dikkat çekmektedir. Bunun gibi tarım alanlarını iyileştirip ürün kalitesini ve birim alanda elde edilecek oranın artırılmasına yönelik çalışmaların yapılmayışı, Merkezî yönetimin tarımda reformist yaklaşımlarda oldukça uzak olduğunu göstermektedir.

XVI. yüzyılın ikinci yarısında gerek Merkezî yönetim gerek ise köylüler, konum ve statülerini sürdürerek yenileşmenin kapısını

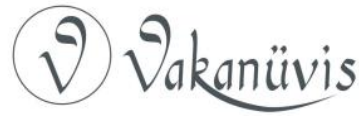


aralayamamışlar ve içerisinde bulundukları sorunlara çözüm yolları üretememişlerdi. Osmanlı Devleti toprak ve tahsildar bağlamında kalarak köylülerin yapısal sorunlarına çözüm bulamamış, sermaye ile vergi bağlamından çıkamamış ve tarımsal sorunların üstesinden gelememişti. Yani tarımda reformist politikanın öncülüğünü yapamamıştı. Bunun gibi toprak üzerinde kiracı konumunda bulunan, sermayesi bir çift öküz ile saban olan, iklimsel faktörlerle mücadelede yetersiz kalan, kullandığı araç ve gereçleri iyileştirmek için çapalamayan köylüler, üretimden pazara karşılaştığı sorunları da çözmekte yetersiz kalmışlardı.

\section{Kaynakça}

\section{Arşiv Belgeleri}

BOA MD 23: 31, 37, 39, 42, 53, 65, 78, 82, 103, 128, 149, 184, 391, 607, $613,622$.

BOA, MD 24: 23, 24, 30, 103, 225, 242, 311.

BOA, MD 26: 87, 114, 291, 308.

BOA, MD 27: 23, 62, 292, 293, 305, 327, 307, 363, 378.

BOA, MD 28: 42.

BOA, MD 48: 92, 132, 172, 314.

BOA, MD 54: 18.

BOA, MD 57: 143.

BOA, MD 67: 44.

BOA, MD 68: 26.

BOA, MD 69: 27, 66-2, 223, 235, 240.

BOA, MD 70: 18. 61 .

BOA, MD 71: 8 .

BOA, MD 72: 214, 259.

BOA, MD 73: 30, 31, 87, 157, 263.

\section{Kitap ve Makaleler}

ALBAYRAK, S., Budin Kânunnâmesi ve Osmanlı Toprak Meselesi, Tercüman Yayınları, İstanbul, 1973.

BARKAN, Ö. L., Osmanlı Devleti'nin Sosyal ve Ekonomik Tarihi, Tetkikler Makaleler, İstanbul Üniversitesi Rektörlük Yayınları, Yayına Hazırlayan: Hüseyin Özdeğer), İstanbul, 2000.

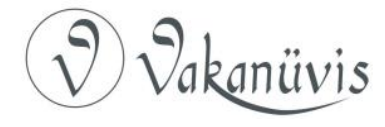


BARKEY, K., Eşkıyalar ve Devlet Osmanlı Tarzı Devlet Merkezîleşmesi, Çev.: Zeynep Altıok, (II. Baskı), Tarih Vakfı Yurt Yayınları, İstanbul, 2011.

GENÇ, M., Osmanlı Imparatorluğunda Devlet ve Ekonomi, (XI. Basım), Ötüken Yayınları, İstanbul, 2014.

TURAN, G., "XVI Yüzyılda Uşak Kazası”, XIII. Türk Tarih Kongresi (Kongreye Sunulan Bildiriler), Cilt III., Kısım III., Ankara, 1999, ss. 1365-1388.

KARADEMIR, Z., Imparatorluğun Açlıkla Imtihanı Osmanlı Toplumunda Kıtlıklar (1560-1660), Kitap Yayınevi, II. Baskı, İstanbul, 2017.

KARTA, N., “Kuruluştan Tanzimat'a Osmanlı İmparatorluğu'nda Para Kredi ve Faiz Politikaları Üzerine Bir Değerlendirme", JASSS, 2018, Sayı: 69, ss. 381395.

Başbakanlık Osmanlı Arşivi Rehberi, Yay. Haz.: Yusuf İhsan Genç vd., Osmanlı Arşivi Daire Başkanlığı, İstanbul, 2010.

iNALCIK, H., Osmanlı Imparatorluğu'nun Ekonomik ve Sosyal Tarihi (13001600), Eren Yayınları, İstanbul, 2000.

iSLAMOĞLU, H., Osmanlı Imparatorluğu'nda Devlet ve Köylü, Illetişim Yayınları, İstanbul, 2010.

ÖZ, M., "Tarımda Verimlilik Problemi XVI. Yüzyılda Uşak Kazası", XIII. Türk Tarih Kongresi (Kongreye Sunulan Bildiriler), Cilt III., Kısım III., Ankara, 1999, ss. 1643-1649.

ÜNAL, M. A., Osmanlı Sosyal ve Ekonomik Tarihi, Paradigma Yayınları, İstanbul, 2012.

ŞAHIN, H., "Klasik Dönem Osmanlı Ekonomisinde İktisadi Kontrol Araçları", Bartın Üniversitesi i.i.B.F. Dergisi, V/10 (2014), ss. 163-186.

TABAKOĞLU, A., Toplu Makaleler I iktisat Tarihi, Bayrak Matbaası, İstanbul, 2005.

YILMAZ, H. F., 16. Yüzyıl Osmanlı Ekonomisinde Piyasa'nın Karşıtı Pazar, Ötüken Yayınları, İstanbul, 2012.

YILMAZ, S., III. Murat Döneminde Divân-ı Hümâyûn Gündeminde Osmanlı Köyü ve Köylüsü, Gazi Üniversitesi Sosyal Bilimler Enstitüsü Yayınlanmamış Doktora Tezi, Ankara, 2017.

WHITE, S., Osmanlı'da Isyan Iklimi Erken Modern Dönemde Celali İsyanları, Alfa Yayınları, İstanbul, 2011. 